University of New Hampshire

University of New Hampshire Scholars' Repository

Languages, Literatures, and Cultures

Scholarship

Languages, Literatures, and Cultures

3-1-1995

\title{
Ideas: Let's Play Bingo: A New Way to Learn Numbers, Vocabulary, and Verbs
}

Lina Lee

University of New Hampshire, Durham, lina.lee@unh.edu

Follow this and additional works at: https://scholars.unh.edu/lang_facpub

Part of the Spanish and Portuguese Language and Literature Commons

\section{Comments}

Copyright (C) 1995 American Association of Teachers of Spanish and Portuguese. This article first appeared in Hispania 78:1 (1995), 161-162. Reprinted with permission by Johns Hopkins University Press.

\section{Recommended Citation}

Lee, Lina. Let's play bingo: A new way to learn numbers, vocabulary and verbs. Hispania, 78(1), 161-162, 1995. https://dx.doi.org/10.2307/345239

This Article is brought to you for free and open access by the Languages, Literatures, and Cultures at University of New Hampshire Scholars' Repository. It has been accepted for inclusion in Languages, Literatures, and Cultures Scholarship by an authorized administrator of University of New Hampshire Scholars' Repository. For more information, please contact Scholarly.Communication@unh.edu. 


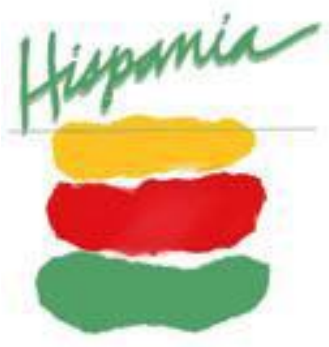

Ideas: Let's Play Bingo: A New Way to Learn Numbers, Vocabulary, and Verbs Author(s): Lina Lee

Source: Hispania, Vol. 78, No. 1 (Mar., 1995), pp. 161-162

Published by: American Association of Teachers of Spanish and Portuguese

Stable URL: http://www.jstor.org/stable/345239

Accessed: 30-05-2017 18:41 UTC

JSTOR is a not-for-profit service that helps scholars, researchers, and students discover, use, and build upon a wide range of content in a trusted digital archive. We use information technology and tools to increase productivity and facilitate new forms of scholarship. For more information about JSTOR, please contact support@jstor.org.

Your use of the JSTOR archive indicates your acceptance of the Terms \& Conditions of Use, available at

http://about.jstor.org/terms

American Association of Teachers of Spanish and Portuguese is collaborating with JSTOR to digitize, preserve and extend access to Hispania 
EDAGOGY: ELEMENTARY AND MIDDLE SCHOOLS, FLES* $(K-8)$

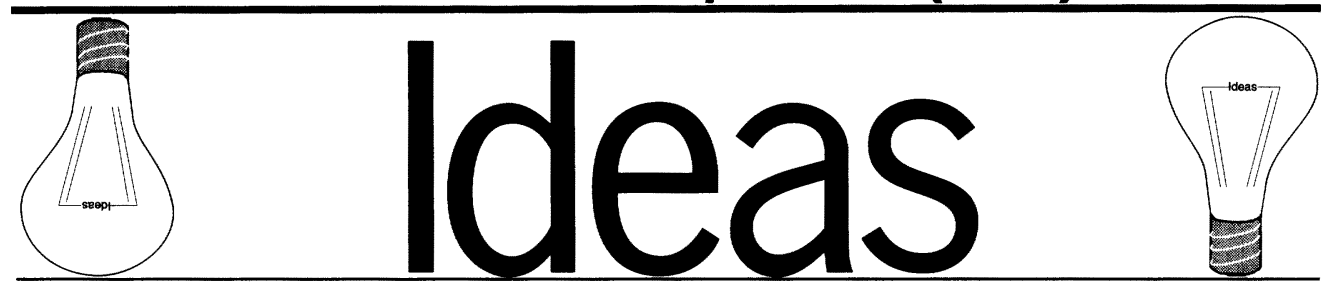

Prepared by Gladys C. Lipton

\title{
Let's Play Bingo: A New Way to Learn Numbers, Vocabulary, and Verbs
}

\author{
Lina Lee \\ State University of New York, Plattsburgh
}

Abstract: The objective of this activity is to help beginning students learn numbers, and practice vocabulary and verbs in an interesting and meaningful way. In addition, this activity attempts to improve their listening comprehension and speaking ability.

Key Words: games, vocabulary, verbs, numbers, bingo, loteria

$\mathbf{M}$ any beginning students have the difficulty of understanding numbers as well as of composing simple sentences in a foreign language. The activity of "Vamos a jugar a la lotería" is a great way for practicing Spanish by listening, asking, and answering questions to each other as well as reinforcing what they have just learned in the classroom. In addition, it creates interaction among students.

The following is an example of playing loteria with numbers. The instructor decides the range of the numbers to play, for example from one to a hundred, writes the numbers on paper, and cuts them into small pieces to place in a plastic bag or a box. The instructor also brings pinto beans for the students to mark the items on their cards.

Each student prepares a cardboard bingo chart of 12 blocks $(3 \times 4)$ or 16 blocks $(4 \times 4)$. They then write the desired numbers within the selected range in the boxes on their cards, as illustrated below:

\begin{tabular}{rrrr}
\multicolumn{4}{c}{ Lotería (0-100) } \\
27 & 7 & 87 & 13 \\
3 & 68 & 100 & 99 \\
43 & 33 & 2 & 70 \\
15 & 6 & 0 & 56
\end{tabular}

As the instructor reads numbers from the bag, students place a pinto bean on the number they hear that matches the number on the bingo card, taking care to mix the numbers well before drawing them. Before the game, the instructor explains the following rules to students in Spanish:

(1) Primero se van a decidir las alternativas para ganar (una fila completa o tarjeta completa)

(2) Se dirá cada número tres veces

(3) Hay que colocar un frijol en el cuadro que corresponde al número leído

(4) Se dice "lotería" en voz alta cuando uno gane la lotería

(5) Se van a leer los números otra vez para comprobar los números de la cartilla ganadora

(6) Se le premiará al ganador con dulces o con crédito extra [optional] 
A variety of this activity is to ask students to write a short phrase on each box of the bingo chart, such as "Tener una familia loca" or "Tener un tío soltero" in Spanish. The instructor can choose the thematic topic, such as "familia," "viaje," and "fin de semana" activities for students to create a set of sentences to write on the bingo chart. Some examples for family situations that students can write on their cards follow:

\section{Lotería (Familia)}

una familia loca

una madre que trabaja

un pariente que bebe mucho

más de cuatro hermanos

un tío divorciado

una tía que cocina bien

una sobrina que canta bien

un padre que fuma

un pariente de México

una cuñada rica

más de siete tíos

una hermana casada

un hermano menor

gemelos/as en la familia

un primo que vive en Tejas

cuatro abuelos vivos
Instead of the intructor's reading phrases, the students themselves present each situation to their classmates. Once they get a " $s i$ " answer of confirmation, they ask the classmate to sign his or her name in the square. Students continue to play the activity until they have enough signatures to get lotería. In order to evaluate the learning outcome of this activity, the instructor can call on individuals and ask them questions or have them ask each other questions in Spanish at the end of the activity.

This activity can also be used to reinforce grammatical concepts, such as servs estar, gustar, or sabervs conocer. Students can create their own sentences, such as "conocer al presidente de la universidad" or "saber cocinar la comida china" for their bingo chart. Another way of using lotería is to acquire cultural knowledge by asking questions, such as " ¿Cuál es la capital de Cuba?, “QQuién es el presidente de Perú?,” ¿Qué es una sobremesa?," etc. Overall, the activity of loteria is an effective and fun way for students to learn and to practice their numbers, vocabulary, grammatical concepts as well as cultural knowledge in the target language. Students feel less anxious while speaking Spanish and interact actively with their peers by playing lotería. 